\title{
Assessment of the Critical Load of Trace Elements in Soils Polluted by Pyrite tailings. A Laboratory Experiment
}

\author{
M. Díez • M. Simón • I. García • F. Martín
}

Received: 24 April 2008 / Accepted: 27 September 2008/Published online: 24 October 2008

(C) The Author(s) 2008. This article is published with open access at Springerlink.com

\begin{abstract}
Nineteen soil samples (SE Spain) with very different chemical physical properties and developed over different parent materials were contaminated by adding increments of an acidic solution from oxidised pyrite tailings. The quantities of $\mathrm{Cu}, \mathrm{Zn}, \mathrm{Cd}$ and $\mathrm{Pb}$ precipitated by the soil samples were directly and significantly related to the pH-buffering capacity. However, when the contamination caused the $\mathrm{pH}$ to fall below 3.0 the soil tended to release a fraction of the element adsorbed, which increased as the $\mathrm{pH}$ decreased. The quantity of each precipitated element at which the action value for each element is reached, was also directly related to the $\mathrm{pH}$-buffering capacity. Nevertheless, in carbonate-rich soils, the precipitated $\mathrm{Cu}$ and $\mathrm{Zn}$ maintained a relatively high level of bioavailability, while $\mathrm{Cd}$ reached a critical level with a content exceeding $25 \mathrm{mg} \mathrm{kg}^{-1}$, regardless of the $\mathrm{pH}-$ buffering capacity.
\end{abstract}

Keywords Soils · Pyrite tailings · Trace elements . Buffering capacity $\cdot$ Critical Load $\cdot$ ph

M. Díez $(\bowtie) \cdot$ F. Martín

Soil Science Department, Faculty of Sciences,

University of Granada,

Campus Fuentenueva s/n,

18002 Granada, Spain

e-mail: mardiezort@hotmail.com

M. Simón • I. García

Soil Science Department, CITE IIB, University of Almería, Carretera Sacramento $\mathrm{s} / \mathrm{n}$,

04120 Almería, Spain

\section{Introduction}

Under natural conditions, the concentration of trace elements in the soil is relatively low, but certain human actions, such as agriculture, (Kabata-Pendias 1995), the application of tailings with residues when used as an organic amendment (Plaquart et al. 1999; McBride 2003), the application of solid urban waste as fertiliser, atmospheric particle transport (Alloway 1995; Föstner 1995), as well as mining (Egger 1994; Ripley et al. 1996; Vartanyan 1989), mining accidents (Cabrera et al. 1999; Simón et al. 1998) or continuous atmospheric depositions (Nicholson et al. 2003) can raise contamination above toxic levels. In these cases, the soil is capable of attenuating the mobility of diverse contaminants by, for example, filtration, neutralisation, adsorption and precipitation; these processes inactivate potential toxicity, blocking undesired elements from passing to more sensitive systems such as the air or water. The capacity of each soil to retain metals depends on the soil properties, mainly texture, organic-matter content, ion-exchange capacity, oxide contents, $\mathrm{pH}$, specific surface area and carbonate content (Alloway 1995; Ross 1994). When this capacity is exceeded, the soil ceases to be effective as the protector of the ecosystem (sink) and can even function as a source of toxic substances. The critical load represents "the maximum quantity of a given contaminant that can be supplied to a soil without causing chemical changes leading to long-term harmful effects on ecosystem structure and function" (Hettelingh et al. 1991). 
This study was aimed at estimating the critical load of soils with different properties withstanding a contaminating solution resulting from the oxidation of pyrite tailings with a $\mathrm{pH}$ value lower than 2.0 and containing a high concentration in trace elements such as $\mathrm{Cu}, \mathrm{Zn}, \mathrm{Cd}$ and $\mathrm{Pb}$. This estimation can be made as a function of: (a) maximum concentration of $\mathrm{Cu}, \mathrm{Zn}, \mathrm{Cd}$ and $\mathrm{Pb}$ that precipitate in each soil within the range of pollution considered in this study (MPC, maximum precipitated concentration), (b) concentration of precipitated elements at which action values (AV, action values) or values above which plants and soil solution should be watched (Prüe $\beta$ 1997), are reached (CAV).

When the soil concentration of a certain contaminant approaches the MPC, not only does it exceed its critical load and affect the functioning of the ecosystem, but new additions could reach surface waters and groundwater whereupon the contamination would spread to other ecosystems. At the same time, given that the precipitated elements may remain in bioavailable form, before the MPC is reached, the AV may be reached, at which point the soil would be expected to begin to display harmful effects. Therefore, the structure and functioning of the ecosystem would begin to be visibly affected when the soil reaches the AV, whereas when it reaches the MPC the surrounding ecosystems would also be visibly affected.

\section{Materials and Methods}

\subsection{Soil Properties}

The soil samples belong to the provinces of Granada and Jaen located in the southeast of Spain. The selected soil samples represent a heterogeneous range of soils with different chemical properties and developed over different parent materials (Table 1).

Soil samples were air dried and then screened to $2 \mathrm{~mm}$ to analyse them. Particle size distribution was determined by the pipette method after elimination of organic matter with $\mathrm{H}_{2} \mathrm{O}_{2}$ and dispersion with sodium hexametaphosphate (Loveland and Whalley 1991). The $\mathrm{pH}$ was measured potentiometrically in a $1: 2.5$ soil-water and soil $0.1 \mathrm{~mol} \mathrm{l}^{-1} \mathrm{KCl}$ suspension. The calcium carbonate equivalent content $\left(\mathrm{CaCO}_{3}, \%\right)$ was determined by the method of Bascomb (1961). Total carbon was analysed by dry combustion with a LECO SC-144DR instrument. Organic carbon (OC) was determined by the difference between total carbon and inorganic carbon from $\mathrm{CaCO}_{3}$. The cation-exchange capacity (CEC) was determined with $1 \mathrm{M} \mathrm{Na}$ acetate at $\mathrm{pH} 8.2$, measuring sodium in a Meteor NAK-II flame-photometer. Exchange bases were determined with $1 \mathrm{M} \mathrm{H}_{4} \mathrm{~N}$ acetate at $\mathrm{pH}$ 7.0, measuring sodium and potassium in a Meteor NAK-II flame-photometer and calcium and magnesium by atomic absorption spectrometry in a Varian SpectrAA 220FS machine, the specific surface area (SA) determined by weighing the water adsorbed by the sample from a solution saturated with $\mathrm{CaCl}_{2}$ (Keeling 1961); total iron $\left(\mathrm{Fe}_{\mathrm{d}}\right)$ and aluminium $\left(\mathrm{Al}_{\mathrm{d}}\right)$ oxides and oxi-hydroxides of the soil samples were extracted with citrate-dithionite (Holmgren 1967).

\subsection{Contaminating Solution (CS)}

Ten grams of pyrite tailings from the mining spill at Aznalcóllar (Seville, Spain) were placed in contact for 3 days with $1,000 \mathrm{~cm}^{3}$ of $\mathrm{H}_{2} \mathrm{O}_{2}$ at $15 \%$. The contaminating solution (CS) presented a $\mathrm{pH}$ of 1.7 and a concentration in $\mathrm{Cu}, \mathrm{Pb}, \mathrm{Zn}$ and $\mathrm{Cd}$ of 14.5, 3.2, 55.4 and $0.21 \mathrm{mg} \mathrm{dm}^{-3}$, respectively (more details of the contaminating solution composition is given in Simón et. al. 1999).

\subsection{Spiked Soils}

According to their properties, different quantities of CS were added to soil samples. Thus, 1, 1.5, 2, 3 and $5 \mathrm{~cm}^{3} \mathrm{CS} \mathrm{g}^{-1}$ were added to the sandy and acid soils $(\mathrm{pH}<7.0) ; 1,2,4,6$ and $10 \mathrm{~cm}^{3} \mathrm{CS} \mathrm{g}^{-1}$ were added to soils with a sandy-loam texture or finer and $\mathrm{pH}>$ 7.0 and $\mathrm{CaCO}_{3}<2 \% ; 2,6,10,15$ and $20 \mathrm{~cm}^{3} \mathrm{~g}^{-1}$ were added to soils with a loamy texture or finer, pH>7.5 and $\mathrm{CaCO}_{3}$ between $2 \%$ and $30 \%$; and 10 , $20,30,40$ and $50 \mathrm{~cm}^{3} \mathrm{~g}^{-1}$ were added to soils with a loamy texture or finer, $\mathrm{pH}>8.0$ and $\mathrm{CaCO}_{3}>30 \%$. After $72 \mathrm{~h}$ of shaking (Alonso et al. 1997), each soil extract-CS was measured for $\mathrm{pH}$ and centrifuged at 3,000 rpm for $15 \mathrm{~min}$, separating the solid and liquid fractions.

\subsection{Total Water and $\mathrm{NH}_{4} \mathrm{NO}_{3}$ Extractable Trace Element Concentrations}

To determine water soluble forms, soil-water extracts were prepared in a ratio 1:10 (Norma DIN 38 414-4) 
Table 1 Physico-chemical properties of the studied soils

\begin{tabular}{|c|c|c|c|c|c|c|c|c|c|}
\hline \multirow[t]{2}{*}{ Samples } & \multirow[t]{2}{*}{ Parent material } & \multirow[t]{2}{*}{$\mathrm{pH}_{\mathrm{H} 2 \mathrm{O}}$} & \multirow[t]{2}{*}{$\mathrm{pH}_{\mathrm{KCl}}$} & \multirow[t]{2}{*}{$\mathrm{CaCO}_{3}(\%)$} & \multirow[t]{2}{*}{ M.O. (\%) } & \multicolumn{3}{|c|}{$\mathrm{cmol}_{\mathrm{c}} \mathrm{kg}^{-1}$} & \multirow[t]{2}{*}{ V $(\%)$} \\
\hline & & & & & & $\mathrm{Ca}$ & $\mathrm{Mg}$ & CEC & \\
\hline $\mathrm{J}-1$ & Quartzite & 6.90 & 5.90 & 0.20 & 1.62 & 2.50 & 0.58 & 3.51 & 35.4 \\
\hline $\mathrm{J}-2$ & Sandstone & 6.80 & 5.50 & 0.70 & 0.96 & 4.25 & 0.82 & 5.62 & 85.8 \\
\hline $\mathrm{J}-3$ & Granite & 5.70 & 4.10 & 0.80 & 5.06 & 2.75 & 0.41 & 8.79 & 46.2 \\
\hline $\mathrm{J}-4$ & Slate & 6.40 & 4.40 & 0.10 & 1.98 & 6.75 & 2.88 & 7.73 & 100 \\
\hline Gr-1 & Filite & 8.20 & 7.20 & 3.30 & 2.50 & 6.00 & 2.99 & 5.62 & 100 \\
\hline Gr-2 & Conglomerate & 6.60 & 4.70 & 1.00 & 1.01 & 10.87 & 3.67 & 16.17 & 77.8 \\
\hline Gr-3 & Limestone & 8.00 & 7.00 & 0.40 & 8.70 & 23.00 & 1.16 & 24.6 & 78.1 \\
\hline Gr-4 & Schist & 7.60 & 6.20 & 0.60 & 3.69 & 9.50 & 2.66 & 12.65 & 100 \\
\hline GR-5 & Schist & 7.70 & 6.60 & 0.70 & 1.93 & 6.50 & 1.08 & 7.03 & 96.5 \\
\hline Gr-6 & Conglomerate & 8.30 & 7.10 & 0.60 & 1.74 & 16.21 & 2.49 & 18.98 & 100 \\
\hline Gr-7 & Limestone & 7.80 & 6.90 & 0.90 & 7.90 & 28.00 & 1.49 & 30.93 & 74.7 \\
\hline Gr-8 & Filite & 8.30 & 7.50 & 19.60 & 5.77 & 12.25 & 5.06 & 15.42 & 83.9 \\
\hline Gr-9 & Limestone & 8.40 & 7.20 & 5.10 & 2.39 & 27.00 & 1.33 & 16.17 & 100 \\
\hline Gr-10 & Evaporite & 7.80 & 7.50 & 56.50 & 1.90 & 41.89 & 4.32 & 13.71 & 100 \\
\hline Gr-11 & Limestone & 8.20 & 7.40 & 22.90 & 2.71 & 30.50 & 1.91 & 18.98 & 100 \\
\hline Gr-12 & Limestone & 8.20 & 7.50 & 59.00 & 3.34 & 27.25 & 1.49 & 15.47 & 100 \\
\hline Gr-13 & Marl-Limestone & 8.40 & 7.20 & 79.60 & 0.85 & 24.25 & 1.00 & 13.36 & 100 \\
\hline Gr-14 & Dolomite & 8.20 & 7.50 & 32.60 & 3.08 & 10.00 & 3.24 & 11.25 & 100 \\
\hline Gr-15 & Dolomite & 8.30 & 7.30 & 84.60 & 1.90 & 4.25 & 3.15 & 12.30 & 100 \\
\hline Sample & $\%$ Sand & $\%$ Silt & $\%$ Clay & $\mathrm{SE}\left(\mathrm{m}^{2} / \mathrm{g}\right)$ & $\mathrm{Fe}_{\mathrm{d}} \%$ & \multicolumn{3}{|c|}{$\begin{array}{l}\mathrm{BC}_{3.5} \\
\left(\mathrm{cmolH}^{+} \mathrm{kg}^{-1}\right)\end{array}$} & \\
\hline $\mathrm{J}-1$ & 59.30 & 28.00 & 12.70 & 4.54 & 0.34 & \multicolumn{3}{|l|}{0.62} & \\
\hline $\mathrm{J}-2$ & 66.30 & 19.20 & 14.50 & 13.73 & 0.73 & \multicolumn{3}{|l|}{0.39} & \\
\hline $\mathrm{J}-3$ & 78.00 & 14.00 & 8.00 & 17.66 & 0.26 & \multicolumn{3}{|l|}{0.47} & \\
\hline $\mathrm{J}-4$ & 57.40 & 32.00 & 10.60 & 34.81 & 0.92 & \multicolumn{3}{|l|}{0.85} & \\
\hline Gr-1 & 58.80 & 23.30 & 17.90 & 14.03 & 0.87 & \multicolumn{3}{|l|}{8.36} & \\
\hline Gr-2 & 32.50 & 13.30 & 54.20 & 108.45 & 2.10 & \multicolumn{3}{|l|}{1.14} & \\
\hline Gr-3 & 60.80 & 16.10 & 23.10 & 69.27 & 0.76 & \multicolumn{3}{|l|}{8.28} & \\
\hline Gr-4 & 67.60 & 21.30 & 11.10 & 43.86 & 0.87 & \multicolumn{3}{|l|}{1.93} & \\
\hline Gr-5 & 68.10 & 19.20 & 12.70 & 19.45 & 1.55 & \multicolumn{3}{|l|}{2.91} & \\
\hline Gr-6 & 33.60 & 15.60 & 50.80 & 100.56 & 2.83 & \multicolumn{3}{|l|}{5.81} & \\
\hline Gr-7 & 23.60 & 55.80 & 20.60 & 111.88 & 2.49 & \multicolumn{3}{|l|}{16.14} & \\
\hline Gr-8 & 49.80 & 28.30 & 21.90 & 32.78 & 1.02 & \multicolumn{3}{|l|}{17.76} & \\
\hline Gr-9 & 41.20 & 27.30 & 31.50 & 76.51 & 1.84 & \multicolumn{3}{|l|}{20.07} & \\
\hline Gr-10 & 22.40 & 55.70 & 21.90 & 43.68 & 0.21 & \multicolumn{3}{|l|}{90.83} & \\
\hline Gr-11 & 43.60 & 31.60 & 24.80 & 78.47 & 0.84 & \multicolumn{3}{|l|}{79.52} & \\
\hline Gr-12 & 38.80 & 37.10 & 24.10 & 54.58 & 0.55 & 82.49 & & & \\
\hline Gr-13 & 22.40 & 41.00 & 36.60 & 62.80 & 0.26 & 81.79 & & & \\
\hline Gr-14 & 40.80 & 33.60 & 25.60 & 29.78 & 1.10 & 63.34 & & & \\
\hline Gr-15 & 38.30 & 58.10 & 3.60 & 3.58 & 0.21 & 50.31 & & & \\
\hline
\end{tabular}

Soil samples are labelled according to the location of the sampling site (Jaen province, $\mathrm{J}$ and Granada province, Gr)

M.O. organic matter, $\mathrm{Ca}$ exchangeable calcium content, $\mathrm{Mg}$ exchangeable magnesium content, $C E C$ cation-exchange capacity, $V$ base saturation percentage, Ss Specific surface, Fed iron oxides 
and then $\mathrm{Cu}, \mathrm{Pb}, \mathrm{Zn}$ and $\mathrm{Cd}$ water extractable concentrations were analysed. Trace element precipitated concentrations (MPC) were determined as the difference between trace element concentration in the CS and water extractable concentration measured in soil water extracts. Finally, the $\mathrm{pH}$ value measured in the soil-water extracts. Soils were also analysed for the trace element concentrations extractable by $\mathrm{NH}_{4} \mathrm{NO}_{3} 1 \mathrm{M}$ (DIN 19730; Prüe $\beta$ 1997). In all cases, the concentration of the different metals $(\mathrm{Cu}, \mathrm{Zn}, \mathrm{Cd}$ and $\mathrm{Pb}$ ) was measured by ICP-MS in a PE SCIEX ELAN-5000 A spectrometer.

Distribution coefficients $\left(K_{\mathrm{d}}\right)$ represent the sorption affinity of the soil solid phase for trace elements in solution and can be used as a valuable tool to study metal-cation mobility and retention in soil systems. The distribution coefficients $\left(K_{\mathrm{d}}\right)$, ratios between the quantity of precipitated element $\left(\mathrm{mmol} \mathrm{kg}^{-1}\right)$ and the quantity remaining in solution $\left(\mathrm{mmol} \mathrm{dm}{ }^{-3}\right)$, were calculated according to Alloway (1995). According to Anderson and Christensen (1988), high $K_{\mathrm{d}}$ values indicate that the metal has been retained by the solid phase through sorption reactions, while low values of $K_{\mathrm{d}}$ indicate that a large fraction of the metal remains in solution.

\subsection{Determination of Buffering Capacity of Soils}

The $\mathrm{pH}$-buffering capacity of soils at $\mathrm{pH}=3.5$ was evaluated $\left(\mathrm{BC}_{3.5}\right)$ as the $\mathrm{cmol}$ of $\mathrm{H}^{+}$needed to reduce soil $\mathrm{pH}$ value up to 3.5 . The titration curves were drawn following the method of Hartikainen (1986), soil samples (air dried, $<2 \mathrm{~mm}$ ) were equilibrated with solutions of increasing concentrations of $10^{-3} \mathrm{M} \mathrm{HCl}$ (soil-solution ratio of $1: 10$ ) while maintaining the ionic strength constant. The suspensions were shaken for $60 \mathrm{~min}$ and then the $\mathrm{pH}$ measured after 4 days of settling; then the amount of $\mathrm{H}^{+}$added were plotted against the equilibrium $\mathrm{pH}$ values (titration curves). From these curves, the values for the acid neutralisation (BC) were determined graphically, this being referred to as the quantity of acid needed to bring the $\mathrm{pH}$ of the soil to a given value (Van Breemen et al. 1983). In the present study, the $\mathrm{pH}$ value of 3.5 $\left(\mathrm{BC}_{3.5}\right)$ was taken as the reference value, like one of the intervals defined by Ulrich (1981) for soils and reflects the aluminium and iron buffer region. Finally, the data were statistically processed using SPSS 12.0 software package.

\section{Results and Discussion}

\section{$3.1 \mathrm{pH}-$ Buffering Capacity}

The main property that marked a significantly different behaviour among the soils was the $\mathrm{BC}_{3.5}$, which was related $(P<0.005)$ to the calcium carbonate content $\left(\% \mathrm{CaCO}_{3}\right)$ and the sum of the exchangeable calcium and magnesium content in soils $([\mathrm{Ca}+\mathrm{Mg}]$ expressed in $\mathrm{cmol}_{\mathrm{c}} \mathrm{kg}^{-1}$ ):

$$
\begin{gathered}
\mathrm{BC}_{3.5}\left(\mathrm{cmol} \mathrm{H}^{+} \mathrm{kg}^{-1}\right)=0.792 \mathrm{CaCO}_{3}+0.870[\mathrm{Ca}+\mathrm{Mg}] \\
r^{2}=0.903
\end{gathered}
$$

indicating that the weathering of the carbonates and the exchange between basic cations (among which $\mathrm{Ca}$ and $\mathrm{Mg}$ are the most abundant) and protons are the main mechanisms controlling soil acidification. In any case, soils with different $\mathrm{BC}_{3.5}$ values show similar $\mathrm{pH}$-buffering capacity pattern in such a way that, based on this pattern, the soils were assigned to three groups (Fig. 1):

1. soils with $\mathrm{BC}_{3.5}<3 \mathrm{cmol} \mathrm{H} \mathrm{kg}^{-1}$, in which the $\mathrm{pH}$ value was reduced rapidly with the addition of $\mathrm{CS}$, reaching $\mathrm{pH}$ values of 3.0 for additions of $\leq 2 \mathrm{~cm}^{3}$ $\mathrm{CS} \mathrm{g}^{-1}$ of soil;

2. soils with $\mathrm{BC}_{3.5}$ between 3 and $20 \mathrm{cmol} \mathrm{H}^{+} \mathrm{kg}^{-1}$, in which the $\mathrm{pH}$ decreased gradually, reaching values of 3.0 for relatively lower concentration of contaminating solution (between 2 and $4 \mathrm{~cm}^{3} \mathrm{CS} \mathrm{g}^{-1}$ of soil);

3. soils with $\mathrm{BC}_{3.5}>20 \mathrm{cmol} \mathrm{H}^{+} \mathrm{kg}^{-1}$, in which the decline of the $\mathrm{pH}$ was very gradual and in no case reached values of less than 6.5 .

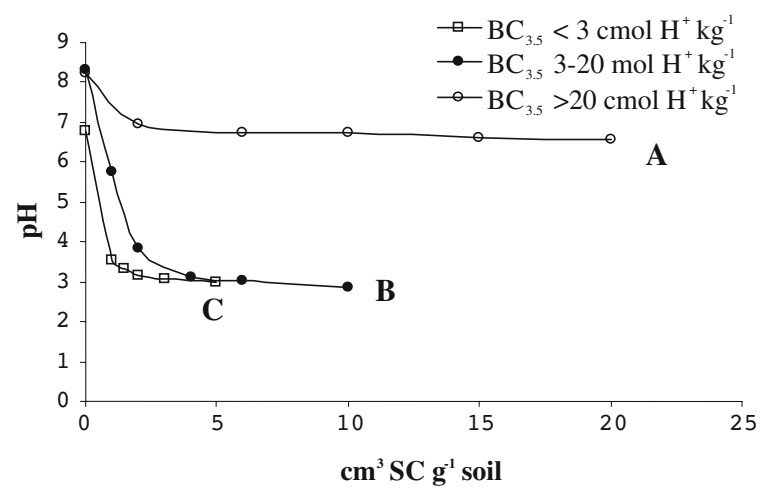

Fig. 1 Changes in $\mathrm{pH}$ values measured in $\mathrm{H}_{2} \mathrm{O}$ of soils with different $\mathrm{pH}$-buffering capacity at $\mathrm{pH}=3.5\left(\mathrm{BC}_{3.5}\right)$ with increasing amounts of contaminating solution added $\left(\mathrm{cm}^{3} \mathrm{SC} \mathrm{g}^{-1}\right.$ soil). (A) $\mathrm{BC}_{3.5}>20 \mathrm{cmol} \mathrm{H} \mathrm{Hg}^{+1}$; $(B) \mathrm{BC}_{3.5}$ between 3 and $20 \mathrm{cmolH}^{+} \mathrm{kg}^{-1}$; (C) $\mathrm{BC}_{3.5}<3 \mathrm{cmol} \mathrm{H}^{+} \mathrm{kg}^{-1}$ 
3.2 Water-extractable Concentrations and Coefficient of Distribution

The coefficient of distribution $\left(K_{\mathrm{d}}\right)$, the ratio between the quantity of the precipitate of each element $\left(\mathrm{mmol} \mathrm{kg}^{-1}\right)$ and the quantity that remained in solution $\left(\mathrm{mmol} \mathrm{dm}^{-3}\right)$, revealed that the precipitation rate of the different trace elements was related to the $\mathrm{BC}_{3.5}$. Thus, the greatest proportion of water extractable trace elements concentration was found in soils with $\mathrm{BC}_{3.5}<3 \mathrm{cmol} \mathrm{H}^{+} \mathrm{kg}^{-1}$ (Fig. $2 \mathrm{~A}$ ), followed by those with $\mathrm{BC}_{3.5}$ between 3 and $20 \mathrm{cmol} \mathrm{H}^{+} \mathrm{Kg}^{-1}$ (Fig. $2 \mathrm{~B}$ ); meanwhile, the greatest precipitation rate was registered for soils with $\mathrm{BC}_{3.5}>$ $20 \mathrm{cmol} \mathrm{H}^{+} \mathrm{Kg}^{-1}$ (Fig. 2 C). Similarly, the $K_{\mathrm{d}}$ values showed high solubility of $\mathrm{Cd}$ and $\mathrm{Zn}$ as opposed to $\mathrm{Cu}$ and $\mathrm{Pb}$.

In general, within each of the defined groups, the quantity of precipitated metal tended to increase progressively with the ratio CS-soil extract until the maximum retention capacity of each soil (MPC), above which the precipitated metal concentration either tended to remain constant or tended to diminish. The first behaviour was noted in the soils with $\mathrm{BC}_{3.5}>20 \mathrm{cmol} \mathrm{H}^{+} \mathrm{kg}^{-1}$ (Fig. 3, Gr13), whereas the soils with $\mathrm{BC}_{3.5}<20 \mathrm{cmol} \mathrm{H}^{+} \mathrm{kg}^{-1}$ displayed the second behaviour (Fig. 3, Gr3). Therefore those soils with $\mathrm{BC}_{3.5}<20 \mathrm{cmol} \mathrm{H}^{+} \mathrm{kg}^{-1}$ could thus become a source of contamination when the MPC is exceeded (chemical time bomb; Stigliani 1988). In general, this

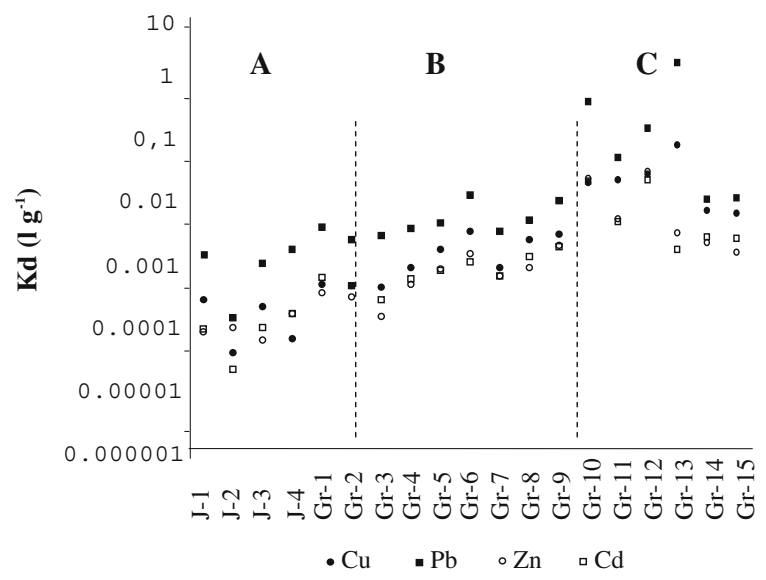

Fig. 2 Distribution coefficient for $\mathrm{Cu}, \mathrm{Pb}, \mathrm{Cd}$ and $\mathrm{Zn}$ in the studied soils, calculated at a dosage of $500 \mathrm{mg} \mathrm{kg}^{-1}$ of SC $\left(K_{\mathrm{d} 500}\right)$. In the graph, we can distinguish between $(A) K_{\mathrm{d} 500}$ of soils with $\mathrm{BC}_{3.5}<3 \mathrm{cmol} \mathrm{H}^{+} \mathrm{kg}^{-1} ;(B) K_{\mathrm{d} 500}$ of soils with $\mathrm{BC}_{3.5}$ between 3 and $20 \mathrm{cmolH}^{+} \mathrm{kg}^{-1}$; $(C) K_{\mathrm{d} 500}$ of soils with $\mathrm{BC}_{3.5}>$ $20 \mathrm{cmol} \mathrm{H}^{+} \mathrm{kg}^{-1}$

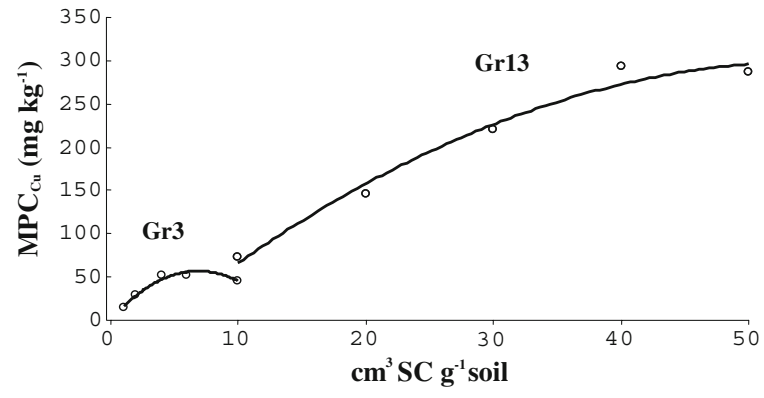

Fig. 3 Graph showing the precipitated concentration of copper with the increasing amount of metal (copper) added with the contaminating solution in soils $\mathrm{Gr}-3$ (with $\mathrm{BC}_{3.5}<20 \mathrm{cmol} \mathrm{H}^{+} \mathrm{kg}^{-1}$ ) and $\mathrm{Gr}-13$ (with $\mathrm{BC}_{3.5}>20 \mathrm{cmol} \mathrm{H} \mathrm{kg}^{-1}$ )

process takes place in the studied soils when the $\mathrm{pH}$ of the soil extract-CS is less than or equal to 3.0.

In any case, these two types of behaviour should be understood within the range of the studied pollution, since at higher contamination rates even the $\mathrm{pH}$ of those soils with $\mathrm{BC}_{3.5}>20 \mathrm{cmol} \mathrm{H}^{+} \mathrm{kg}^{-1}$ could fall to values below 3.0, releasing precipitated elements and thus becoming in a potential threat to the ecosystem exposed to them.

Although $\mathrm{MPC}_{\mathrm{Cu}}, \mathrm{MPC}_{\mathrm{Pb}}, \mathrm{MPC}_{\mathrm{Zn}}$ and $\mathrm{MPC}_{\mathrm{Cd}}$ were significantly related $(p<0.01)$ to the $\mathrm{BC}_{3.5}$, this relationship presented certain particularities, depending on the element. Thus, in the case of $\mathrm{Cu}, \mathrm{Zn}$ and $\mathrm{Cd}$, the relationship between the two parameters was linear:

$\operatorname{MPC}_{\mathrm{Cu}}\left(\mathrm{mg} \mathrm{kg}^{-1}\right)=11.84+3.11 \mathrm{BC}_{3.5}\left(\mathrm{cmol} \mathrm{H}^{+} \mathrm{kg}^{-1}\right) r^{2}=0.965$ $\mathrm{MPC}_{\mathrm{Zn}}\left(\mathrm{mg} \mathrm{kg}^{-1}\right)=13.03+9.35 \mathrm{BC}_{3.5}\left(\mathrm{cmol} \mathrm{H}^{+} \mathrm{kg}^{-1}\right) r^{2}=0.955$ $\operatorname{MPC}_{\mathrm{Cd}}\left(\mathrm{mg} \mathrm{kg}^{-1}\right)=0.124+0.02 \mathrm{BC}_{3.5}\left(\mathrm{cmol} \mathrm{H}^{+} \mathrm{kg}^{-1}\right) r^{2}=0.976$

while $\mathrm{Pb}$ presented a different behaviour, depending on the value of the $\mathrm{BC}_{3.5}$ (Fig. 4). When the $\mathrm{BC}_{3.5}<$ $70 \mathrm{cmol} \mathrm{H}^{+} \mathrm{kg}^{-1}, \mathrm{MPC}_{\mathrm{Pb}}$ was related logarithmically to $\mathrm{BC}_{3.5}$ and tended to reach a constant value. When

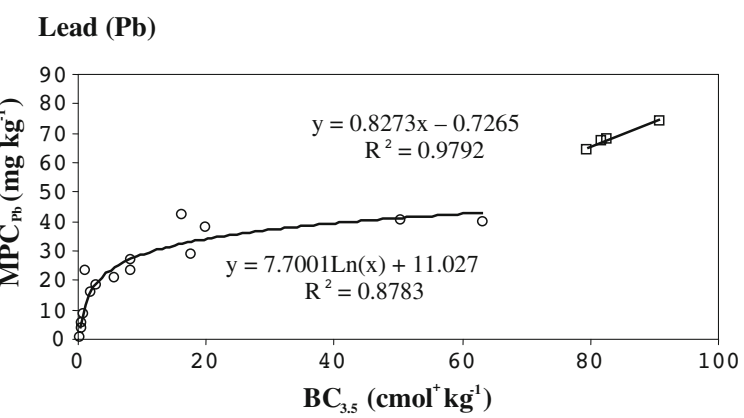

Fig. 4 Relationship between the maximum quantity of $\mathrm{Pb}$ precipitated $\left(\mathrm{MPC}_{\mathrm{Pb}}\right)$ and the $\mathrm{pH}$-buffering capacity $\left(\mathrm{BC}_{3.5}\right)$ 
$\mathrm{BC}_{3.5}>70 \mathrm{cmol} \mathrm{H}^{+} \mathrm{kg}^{-1}$, as in the soils with a very high $\mathrm{CaCO}_{3}$ content, the $\mathrm{MPC}_{\mathrm{Pb}}$ tended to increase linearly.

\subsection{Copper, Lead, Zinc and Cadmium $\mathrm{NH}_{4} \mathrm{NO}_{3}$ Extractable Concentrations}

The relationship between the precipitated and the $\mathrm{NH}_{4} \mathrm{NO}_{3} 1 \mathrm{M}$ extractable concentration for each metal was established. From this relationship, we can deduce the quantity of precipitated metal at which the action level is reached (CAV) accepted by the DIN 19730 guidelines where $\mathrm{AV}$ are reported as $1 \mathrm{mg} \mathrm{Cu} \mathrm{kg}^{-1}$ soil $\left(\mathrm{AV}_{\mathrm{Cu}}\right), 3 \mathrm{mg} \mathrm{Pb} \mathrm{kg}{ }^{-1}$ soil $\left(\mathrm{AV}_{\mathrm{Pb}}\right), 5 \mathrm{mg} \mathrm{Zn} \mathrm{kg} \mathrm{Zn}^{-1}$

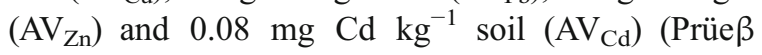
1997). In all cases, the CAV value was also significantly related $(p<0.01)$ to the $\mathrm{BC}_{3.5}$, although with certain particularities (Fig. 5). Thus, the CAV of $\mathrm{Cu}$ and $\mathrm{Zn}$ were related to the $\mathrm{BC}_{3.5}$ through seconddegree equations, differentiating among soils with $\mathrm{BC}_{3.5}<70 \mathrm{cmol} \mathrm{H}^{+} \mathrm{kg}^{-1}$ and $\mathrm{BC}_{3.5}>70 \mathrm{cmol} \mathrm{H}^{+} \mathrm{kg}^{-1}$. It is worth noting that the soils with $\mathrm{BC}_{3.5}>70 \mathrm{cmol}$ $\mathrm{H}^{+} \mathrm{kg}^{-1}$ presented relatively low $\mathrm{CAV}$ values, indicating that, although the highly carbonate soils can precipitate high quantities of $\mathrm{Cu}$ and $\mathrm{Zn}$, their bioavailability is high and can easily get into the food chain.

On the contrary, $\mathrm{Cd}$ and $\mathrm{Pb}$ did not differ. Thus, in all the soils, the $\mathrm{CAV}_{\mathrm{Cd}}$ was related to the $\mathrm{BC}_{3.5}$ according to the logarithmic equation in which there was a tendency for a steady value to be reached (Fig. 5c); this indicates, in general terms, that when the soils presented a $\mathrm{Cd}$ concentration of around $2.5 \mathrm{mg} \mathrm{kg}^{-1}$, they exceeded the critical bioavailability level. In the case of $\mathrm{Pb}$ (Fig. 5d), the relation between $\mathrm{CAV}_{\mathrm{Pb}}$ and $\mathrm{BC}_{3.5}$ was exponential, so that an increase in the neutralisation capacity of soil acids allows a considerable increase in $\mathrm{Pb}$ before the critical bioavailability level is reached.

\section{Conclusions}

The calcium carbonate content together with exchangeable calcium and magnesium content are the main parameters regulating the buffering capacity as well as the critical load of the soils polluted by pyrite tailings. However, these parameters differ between the studied elements, $\mathrm{Cu}, \mathrm{Zn}$, a

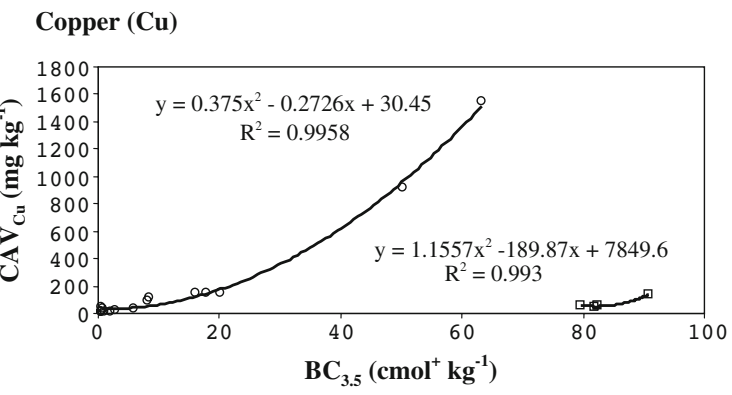

b

Zinc (Zn)

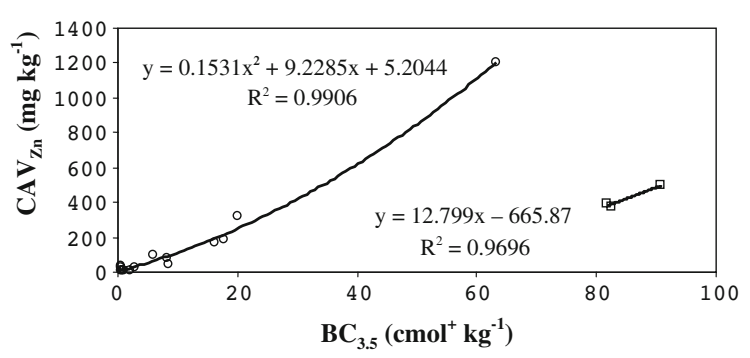

C

Cadmium (Cd)

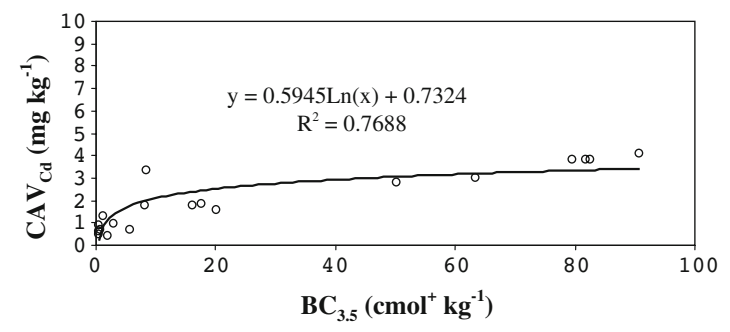

d

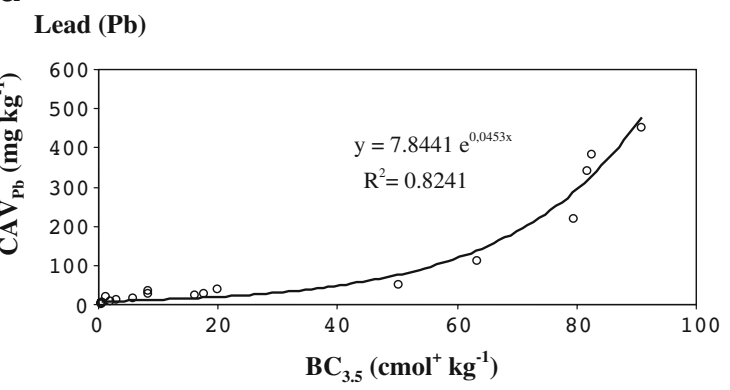

Fig. 5 Relationship between the quantity of metal precipitated $\left(\mathrm{CAV}_{\mathrm{Cu}}\right.$ and $\left.\mathrm{CAV}_{\mathrm{Zn}}\right)$ at which the action value (AV) is reached and the pH-buffering capacity at $\mathrm{pH} 3.5\left(\mathrm{BC}_{3.5}\right)$. Relationship between the quantity of metal precipitated $\left(\mathrm{CAV}_{\mathrm{Cd}}\right.$ and $\left.\mathrm{CAV}_{\mathrm{Pb}}\right)$ at which the action value (AV) is reached and the $\mathrm{pH}$-buffering capacity at $\mathrm{pH} 3.5\left(\mathrm{BC}_{3.5}\right)$ 
$\mathrm{Cd}$ and $\mathrm{Pb}$ in soils. Thus, while the $\mathrm{NH}_{4} \mathrm{NO}_{3}$ extractable $\mathrm{Cu}$ and $\mathrm{Zn}$ concentration tends to increase in highly carbonated soils, the $\mathrm{Pb}$ reduces drastically and the $\mathrm{Cd}$ tends to remain constant regardless of the soil characteristics.

Acknowledgements This study was funded by the Education and Science Ministry of Spain (CTM 2006-01639). Also thanks go to Mr. David Nesbitt for the English translation of this study and comments.

Open Access This article is distributed under the terms of the Creative Commons Attribution Noncommercial License which permits any noncommercial use, distribution, and reproduction in any medium, provided the original author(s) and source are credited.

\section{References}

Alloway, B. J. (1995). The origins of heavy metals in soils. In B. J. Alloway (Ed.), Heavy metals in soils (pp. 38-57). Blackie Academic and Professional.

Alonso, I., Pérez, A. M., Moreno, A. M., \& González, J. (1997). Retención de $\mathrm{Zn}, \mathrm{Cd}, \mathrm{Pb}$ y Cu después del proceso de adsorción-desorción. Boletín de la Sociedad Española de la Ciencia del Suelo, 3.1, 65-73.

Anderson, P. R., \& Christensen, T. H. (1988). Distribution coefficients of $\mathrm{Cd}, \mathrm{Co}, \mathrm{Ni}$ and $\mathrm{Zn}$ in soils. Journal of Soil Science, 39, 15-22.

Bascomb, C. L. (1961). A calcimeter for routine use on soil simples. Chemistry \& Industry, 45, 1826-1827.

Cabrera, F., Clemente, L., Díaz Barrios, E., López, R., \& Murillo, J. M. (1999). Heavy metal pollution of soils affected by the Guadiamar toxic flood. The Science of the Total Environment, 242, 117-129.

Egger, R. G. (1994). Mining and the environment: an introduction and overview. In R. G. Eggert (Ed.), Mining and the environment: International perspectives on public policy (pp. 1-20). Washington DC: Resources for the Future.

Föstner, U. (1995). Land contamination by metals: global scope and magnitude of problem. In H. E. Allen, C. P. Huang, G. W. Bailey, \& A. R. Bowers (Eds.), Metal speciation and contamination of soil (pp. 1-33). Lewis Publishers and CRC.

Hartikainen, H. (1986). Acid-and base titration behavior of Finnish mineral soils. Z. Pflanz. Bodenk., 149, 522-532.

Hettelingh, J. P., Downing, R. J., \& de Smet, P. A. M. (1991). Mapping critical loads for Europe, CCE Technical Report $\mathrm{n}^{\circ} 1$, Netherlands.

Holmgren, G. S. (1967). A rapid citrate-dithionite extractable iron procedure. Soil Science Society of America Journal, 31, 210-211.
Kabata-Pendias, A. (1995). Agricultural problems related to excessive trace metal contents of soils. In W. Salomons, U. Förstner, \& P. Mader (Eds.), Heavy metals. Problems and solutions (pp. 3-18). Springer.

Keeling, P. (1961). The examination of clays by IL/MA. Transactions of the British Ceramic Society, 60, 217-244.

Loveland, P. J., \& Whalley, W. R. (1991). Particle size analysis. In K. A. Smith, \& C. E. Mullis (Eds.), Soil analysis: Physical methods (pp. 271-328). New York: Marcel dekker.

McBride, M. B. (2003). Toxic metals in sewage sludgeamended soils: has promotion of beneficial use discounted the risks. Advances in Environmental Research, 8(1), 519. doi:10.1016/S1093-0191(02)00141-7.

Nicholson, F. A., Smith, S. R., Alloway, B. J., Carlton-Smith, C., \& Chambers, B. J. (2003). An inventory of heavy metals inputs to agricultural soils in England and Wales. The Science of the Total Environment, 311, 205-219. doi:10.1016/S0048-9697(03)00139-6.

Plaquart, P., Bonin, G., Prone, A., \& Massiani, C. (1999). Distribution, movement and plant availability of trace metals in soils amended with sewage sludge composts: application to low metal loadings. The Science of the Total Environment, 241, 161-179. doi:10.1016/S0048-9697(99)00338-1.

Prüe $\beta$, A. (1997). Action values mobile $\left(\mathrm{NH}_{4} \mathrm{NO}_{3}\right.$-extractable) trace elements in soils based on the German national standard DIN 19730. Contaminated Soils 3rd International Conference on the Biogeochemistry of Trace Elements, Paris, (pp. 415-423).

Ripley, E. A., Redmann, R. E., \& Crowder, A. A. (1996). Environmental effects of mining. Delray Beach, Florida: St.Lucie.

Ross, S. M. (1994). Retention, transformation and mobility of toxic metals in soils. In S. M. Ross (Ed.), Toxic metals in soil-plant systems (pp. 63-152). Chichester: Wiley.

Simón, M., Ortíz, I., García, I., Fernández, E., Fernández, J., Dorronsoro, C., et al. (1998). El desastre ecológico de Doñana. Edafología, 5, 153-162.

Simón, M., Ortiz, I., García, I., Fernández, E., Fernández, J., Dorronsoro, C., et al. (1999). Pollution of soils by the toxic spill of a pyrite mine (Aznalcóllar, Spain). Science of Total Environment, 242, 105-115.

Stigliani, W. M. (1988). Changes in valued "capacities" of soils and sediments as indicators of non-linear and time-delayed environmental effects. Environmental Monitoring and Assessment, 10, 245-307.

Ulrich, B. (1981). Ökologische Gruppierung von Bóden nach ihrem chemischen Bodenzustand. Z Pflanzenernähr Bodenkd, 144, 289-305.

Van Breemen, N., Mulder, J., \& Driscoll, C. T. (1983). Acidification and alkalinization of soils. Plant and Soil, $75,283-308$.

Vartanyan, G. S. (ed) (1989). The impact of mining on the environment, parts 1 and 2. In: Proceedings of an International Workshop at Tallinn-Leningrad, 18-25 June. Centre for International Projects GKNT, Moscow. 